\title{
Atheism and the Basis of Morality
}

\section{Stephen Maitzen}

\begin{abstract}
People in many parts of the world link morality with God and see good ethical values as an important benefit of theistic belief. A recent survey showed that Americans, for example, distrust atheists more than any other group listed in the survey, this distrust stemming mainly from the conviction that only believers in God can be counted on to respect morality. I argue against this widespread tendency to see theism as the friend of morality. I argue that our most serious moral obligations - the foundations of what can be called “ordinary morality”-remain in place only if God doesn't exist. In recent years, some atheists have reacted to society's distrust of them by claiming that atheism accommodates ordinary morality just as well as theism does. The truth is even stronger: only atheism accommodates ordinary morality. Logically speaking, morality is not common ground between theists and atheists. Morality depends on atheism.
\end{abstract}

Keywords: God, theism, religious belief, atheism, morality, ethics, obligation, suffering

"I’m not 'out' at my workplace," said...Claire, a 27-year-old arts administrator who asked that her last name not be used. "Because most people think atheists have no morals, I could damage the organization if I'm honest about where I stand on the issue.”

[Oppenheimer 2010]

\section{Introduction}

Many people think that God, and only God, makes us moral. Academic researchers and journalists alike report that people in the Jewish-Christian-Islamic world typically link morality with belief in the God of traditional monotheism and see good ethical values as a crucial benefit of religion. According to survey results published in the American Sociological Review, for example, Americans distrust atheists more than any other group listed in the survey, and this distrust stems mainly from the notion that only believers in God can be counted on to respect morality (Edgell, et al., 2006). As the American ethicist James Rachels puts it,

it is not unusual for priests and ministers to be treated as moral experts.... When the prestigious National Commission for the Protection of Human Subjects of Biomedical and Behavioral Research was organized in the mid-1970s, two seats on the commission were reserved for "ethicists"; those seats went to a Jesuit priest and a professor at the Pacific School of Religion.... Why are clergymen regarded in this way? ... In popular 
thinking, morality and religion are inseparable: People commonly believe that morality can be understood only in the context of [theism]. [Rachels 1999: 53-54]

I expect that statistics would show a similar pattern elsewhere in the Americas and in much of Asia, although perhaps less so in Europe.

It's not only believers who treat morality as inseparable from theism. So do some educated nonbelievers, such as the atheist philosopher J. L. Mackie. Concerning his famous book-length argument against the existence of objective moral obligations, Mackie concedes the following: “[I]f the requisite theological doctrine could be defended, a kind of objective ethical prescriptivity could be thus introduced. Since I think that theism cannot be defended, I do not regard this as any threat to my argument” (Mackie 1977: 48). For Mackie, evidently, traditional theism is both necessary and sufficient for the objectivity of morals.

In this paper, I argue against the widespread tendency to see theism as the actual or potential friend of morality. On the contrary, I argue that morality depends on rejecting theism. Our most serious moral obligations_obligations at the heart of what we might call "ordinary morality”_remain in place only if God doesn’t exist.

As befits a philosopher's contribution, my argument is conceptual rather than empirical. I don't, for instance, argue by emphasizing the many endorsements of cruelty found in the theistic scriptural traditions. Nor do I argue that morality psychologically requires atheism except in this sense: my argument suggests that you can accept both theism and certain basic moral duties without cognitive dissonance only if you ignore theism’s implications. Nor do I offer sociological data, as others have (e.g., Paul 2005, 2009), showing that belief in God is correlated with morally undesirable behavior such as violent crime.

Instead, I argue that the existence of theism's perfect God logically precludes the existence of certain basic moral obligations on our part, such as the obligation to prevent or 
relieve terrible suffering by a child when we easily can. ${ }^{1}$ In brief, we have that obligation only if no perfect being is allowing the child's suffering to occur, and hence only if no perfect being exists. I argue, further, that no recognizable morality remains if we lack even the basic obligation to relieve a child's suffering.

In recent years, some atheists have reacted to society’s distrust of them by claiming that atheism accommodates ordinary morality just as well as theism does (see, e.g., Kurtz 2009). The truth, however, is even stronger: only atheism accommodates ordinary morality. Contrary to what these overly concessive atheists have said, morality isn't common ground between theists and atheists. Morality depends on atheism. ${ }^{2}$

\section{The argument}

According to theism, there exists a supreme being, God, possessing perfect knowledge, power, and goodness. Theism thus expresses a core doctrine of monotheistic religions-including in particular Judaism, Christianity, and Islam—ostensibly subscribed to by billions of people. It's obviously important, then, to recognize the implications of this doctrine. Having perfect knowledge, God knows whenever a child is suffering, knows how to prevent that suffering, and knows if the suffering is (or is likely to be) necessary for, or the best way of achieving, the child's overall well-being. Having perfect power, God can prevent the child's suffering. Having perfect goodness, God can’t do anything morally imperfect.

\footnotetext{
${ }^{1}$ For economy in what follows, I'll refer explicitly to preventing suffering, rather than relieving it, but nothing of substance turns on this choice, because to relieve suffering is simply to prevent more, or worse, suffering.

2 I don’t define “ordinary morality” in this paper, because I don’t think it has a nontrivial definition. Even so, we can identify some obligations that belong uncontroversially to it. There are hard cases, but some cases are easy, such as the obligation we at least sometimes have to prevent easily preventable, horrific suffering by a child.
} 
With these implications in mind, consider what is unfortunately a gross understatement: somewhere in the world, right now, a child is experiencing terrible suffering that the child doesn't want and doesn't deserve. Now suppose that God, although having the knowledge and power to prevent it, lets the aforementioned child experience terrible suffering not because the child will ultimately benefit from it but for some other reason, or perhaps for no reason at all. The suffering is intense, the child doesn't deserve to undergo it, and the child doesn't volunteer for it (as someone might volunteer for the pain of donating bone marrow). In allowing the suffering, God exploits the child and thereby acts imperfectly.

The treatment is what's important here, not the exact term we use for it, so you can reject my assumption that we actually use the word "exploit" in this way. My claim is that no supreme being could treat the child in the way I've described, whichever label we choose for that treatment. To put it mildly, there's something less than perfect about letting a child suffer terribly for the primary benefit of someone else-whether for the benefit of a bystander who gets a hero's chance to intervene, or for the benefit of a child-abuser who gets to exercise unchecked free will. If you doubt the previous sentence, consider whether you would dream of letting a child you love suffer abuse in order to secure either of those benefits.

But is it always wrong, one might ask, to exploit people? Don’t we sometimes justifiably use innocent people for the benefit of others? If the child in my example contracts an untreatable, fatal and highly contagious disease, might we not justifiably quarantine him or her when it's the only (or best) way to prevent the spread of the disease? Might we not justifiably isolate the child in a way that benefits others at the expense of the child? Don't we justifiably perform triage, letting some patients suffer so we can attend to more urgent cases? Yes. But these practices reflect our imperfection: it's only limitations in our knowledge and power (in this 
case, medical) that make us resort to triage or quarantine. We regret having to do it; we wish we had the resources to make these practices unnecessary.

A perfect God, however, isn’t subject to our limitations in knowledge or power, or indeed any real limitations in knowledge or power. So no perfect God has an excuse for exploitation, even if we sometimes do. Furthermore, if God were to face an actual moral dilemma, a case in which he does something immoral no matter what he does, then he wouldn't count as morally perfect, on the obvious assumption that a morally perfect being never does anything immoral. If I'm right, then God can't possibly allow a child's intense, undeserved and involuntary suffering unless the suffering is necessary (or if not necessary then optimal) for the child's overall benefit. ${ }^{3}$

Yet many children endure intense, undeserved and involuntary suffering every day, all over the world. What does ordinary morality tell us to do when we encounter them? Obviously, we ought to act compassionately toward them. We have a duty to prevent their suffering, at least when we easily can. Their suffering is very bad for them, which is the most important reason we ought to act with compassion in the first place. But wait. If God exists, then that suffering must be needed—somehow, even if we can't see how—-for the overall benefit of those very sufferers. In that case, what happens to the moral duty we thought we had to prevent their suffering? It disappears.

If a perfect God exists, then any suffering that occurs is suffering that God allows to occur, since any perfect being has the power to prevent any occurrence, including any case of

${ }^{3}$ A number of prominent theistic philosophers have defended precisely this reasoning, among them the Christian philosopher Eleonore Stump, who writes that "if a good God allows evil, it can only be because the evil in question produces a benefit for the sufferer and one that God could not produce without the suffering” (Stump 1985: 411-12) and "other things being equal, it seems morally permissible to allow someone to suffer involuntarily only in case doing so is a necessary means or the best possible means in the circumstances to keep the sufferer from incurring even greater harm” (Stump 1990: 66). 
suffering. If perfection also rules out exploitation, as I've argued it does, then God allows the suffering of children only if those children ultimately benefit from the suffering. The word “from” matters here. It's not enough if God merely compensates children for suffering he lets them endure; the suffering must be necessary (or at least optimal) for their greater good.

Why? Because compensation doesn't count as justification. I can compensate you after harming you, and indeed a court of law may make me compensate you, but no amount of compensation will justify my harming you. The only thing that could justify my harming you would be my need to harm you in order to stop you from harming me or some innocent third party. Likewise, then, for God's permission of a child's suffering: the suffering must be needed, or at least optimal, for the child’s overall benefit. Otherwise God can’t justifiably allow it.

But if the suffering is needed, or optimal, for the child's overall benefit, then it's like the pain from a needle when the needle is the only (or the best) way to deliver a vaccine. If so, then we never have a duty to prevent the suffering of children; after all, we don’t think we have a moral obligation to prevent painful vaccinations when they're beneficial. Even those who oppose childhood vaccinations wholesale do so because they think vaccines do more harm than good. We don't think it’s truly compassionate to prevent all vaccinations just because needles hurt.

If we never have a moral obligation to prevent suffering by children-a consequence implied by the core doctrine of theism — then which moral obligations do we have? None, as far as I can see. I can't see how we can be objectively obligated to refrain from theft, fraud, bigotry, or slander if we never have the even more basic obligation to prevent suffering by children. If we lack a moral obligation to prevent even the worst suffering by children, then morality falls 
apart, or at best it becomes frivolous because it no longer concerns the most serious kinds of harm.

Theism causes a related problem as well. Suppose I'm wrong and we can reconcile God's existence with a duty on our part to prevent at least some suffering. Theism still encourages a bizarre "reverse triage”: the worse an innocent person's suffering, the more reason theism gives us for thinking that the suffering must be needed for the sufferer's own good, and hence the less reason it gives us to prevent the suffering. Theism implies that we ought to prevent mild suffering first, extreme suffering later. Far from shoring up our moral outlook, adding God to it turns it upside down.

\section{Can God exploit?}

Some might try to answer my argument by rejecting its key premise, by countering that a perfect God can allow a child to suffer for the primary benefit of others. Oxford philosopher Richard Swinburne, for instance, says that God has moral permission to exploit any human being because all human beings owe their existence to God, God is on balance their benefactor, and furthermore "being of use is a good for the victim" who gets used (Swinburne 1995: 81). Does Swinburne's reply work? Not at all, as we'll see.

Imagine that I clone a child into existence from a single one of my skin cells, and I treat the child splendidly for all but the final minute of its life. But during that final minute, I let someone abuse the child to death in order to show onlookers just how revolting child-abuse is and thereby deter them from ever abusing a child. Think of it as aversion therapy. The child owes its existence to me (via my use of technology), and I'm on balance its benefactor, treating it well for all but the final minute of its life. Moreover, its horrific death isn’t purely gratuitous; it serves as an object lesson for the benefit of others, not only deterring some potential child- 
abusers but also protecting children they might otherwise have abused. Nevertheless, in this story I behave imperfectly, to say the least. Yet I behave just as Swinburne imagines God does. Even granting Swinburne’s premises, therefore, his conclusion doesn’t follow. His defense of exploitation on the part of a perfect God therefore fails.

\section{Net benefit?}

I’ve argued that no perfect being can exploit a child by allowing the child to experience undeserved, involuntary suffering unless it's necessary or optimal for the child's overall good. In other words, the suffering must be necessary, or at least optimal under the circumstances, for securing a net benefit for the child, whether in this life or the next. Maybe the suffering is an essential means of securing the child's net benefit, or maybe it's an unavoidable byproduct of doing so. One might wonder, however, whether a perfect being must secure for the sufferer a net benefit or instead merely some benefit or other.

To see why perfection requires securing a net benefit for the sufferer, imagine that God lets Jack endure undeserved, unwanted, and unbearable pain because it's the only way to get Jill (the object of Jack's unrequited affection) to send Jack, of her own volition, a get-well card that he'll read just before he dies from his painful condition. Jack secures some benefit from the suffering — a freely sent get-well card from Jill—but suppose that his suffering is involuntary in that he wouldn't regard the benefit as remotely worth the suffering even if he knew that not even God could produce the benefit any other way. Surely God's conduct in that case falls short of moral perfection. It falls short even if we also suppose that Jack's suffering produces significant benefits for others obtainable no other way; maybe news of his suffering triggers generous donations that his hospital wouldn’t otherwise have received. It falls short of moral perfection because it's unjust to Jack. It violates a moral standard demanding fairness in the treatment of 
individual persons, a standard that no perfect being could have an excuse for violating even if we imperfect beings perhaps could. ${ }^{4}$ Jack gets some reward but not enough, because his reward fails, by any reasonable measure, to offset his suffering.

\section{Not truth but belief}

I've argued that the truth of theism would undermine an obligation at the heart of ordinary morality: the obligation we have on at least some occasions to prevent undeserved, involuntary suffering, such as that experienced by children. One might object, however, that it's not the truth of theism that undermines this obligation so much as the belief that theism is true. According to this objection, we lack an obligation to prevent suffering only if we believe that suffering always benefits the sufferer, regardless of whether our belief is true.

I won't try to settle here the complex issue of how our obligations depend on our beliefs. Even if the objection succeeds, however, it's noteworthy enough if ordinary moral obligations dissolve in the presence of theistic belief. But I doubt the objection succeeds in any case. Our ordinary moral obligation to prevent at least some kinds of suffering surely depends on the presumption that suffering is in fact often bad overall for the sufferer. Granted, we recognize that suffering is sometimes on balance worth it for the sufferer; otherwise we'd feel obligated to prevent every vaccination that hurts or every surgery that leaves the patient with a painful recovery. But we feel obligated to prevent suffering in other cases because we confidently presume that the suffering isn't in the sufferer's best interest, or is at least vanishingly unlikely to be. Consider, for instance, the case of the four-year-old boy in Michigan who was tortured to

\footnotetext{
${ }^{4}$ Note that this moral standard can constrain the conduct of a perfect being even if the standard isn't part of ordinary morality — which, as the label suggests, concerns the conduct of imperfect beings like us.
} 
death for wetting his pants. ${ }^{5}$ Had you been in a position to prevent that torture, easily and at no risk to yourself, ordinary morality would have regarded you as obligated to try. Why? At least partly because, we assume, the torture wasn't—or was vanishingly unlikely to be —in the boy's overall interest. Ordinary morality itself thus presupposes that not all undeserved, involuntary suffering is for the overall good of the sufferer, whereas theism implies that it must be. Hence theism and ordinary morality conflict.

\section{Autonomy}

One might try to reconcile theism and ordinary morality by showing that we can have a moral obligation to prevent some action even if we know the action won't cause anyone to suffer except as needed for securing his or her overall good. Suppose that an otherwise normal adult is unwilling to receive a vaccination that he knows will benefit him overall (even factoring in the pain of the needle) by making him immune to a virus ravaging his community. According to this objection, we can have a duty to prevent the vaccination, at least if we easily can, because it violates the recipient's autonomy. ${ }^{6}$

The objection fails for three reasons. First, it's not at all clear that an otherwise beneficial violation of an agent's autonomy is something that a third party has a duty to prevent. Even if I have a duty not to violate your autonomy by benefitting you against your will, it's another matter whether (say) your friend has a duty to try to stop me from doing so. The former duty wouldn't imply the latter.

5 "Police: Man tortured 4-year-old to death for wetting his pants," http://www.cnn.com/2010/ CRIME/04/15/michigan.child.torture (accessed 26 May 2011).

${ }^{6}$ I owe this objection to Robert Lovering. 
Second, the objection is irrelevant to my argument. I've argued that theism threatens our ordinary moral obligation to prevent suffering. Yet in the objector's example it's not suffering that we're obliged to prevent but instead a violation of autonomy, and violations of autonomy can be painless and no less violations of autonomy for being painless. (Imagine a serious violation of your privacy that you never learn about.) So the example doesn't in fact rescue an obligation to prevent suffering.

Third, the objection has very limited scope even if it does establish some obligation to intervene: it works only for autonomous agents. Yet our ordinary moral obligation to prevent suffering is often weightiest when the sufferer lacks autonomy, as in the case of a young child. We have an especially strong moral obligation to prevent the torture of a child when we easily can but no obligation at all to prevent an unwilling child's beneficial vaccination. Autonomy, equally lacking in both cases, does nothing to account for this difference. Our duty to prevent the torture, but not the vaccination, stems from something else: the extreme net harm that the torture causes the child. But I've argued that extreme net harm can't happen to the child if God exists.

\section{Free will}

In my experience, theists feel strongly inclined to reply to my argument by claiming that God must never interfere with the freedom of a human agent, not even to stop the agent from torturing a child, or at least that God's desire to respect the torturer’s freedom can justify God in allowing the torture. ${ }^{7}$ On this view, contrary to what I've argued, God can allow suffering that it then

\footnotetext{
${ }^{7}$ Theistic appeals to free will arise whenever I present this argument, including at a session of the American Philosophical Association Eastern Division Meeting at which my commentator based his criticism of my argument almost entirely on the idea that God would never curtail human freedom.
} 
becomes our duty to prevent, and so we retain the ordinary moral obligation that I've argued theism threatens. The obvious rejoinder, however, is that God's allowing child-torture so as not to interfere with the torturer's freedom is a clear case of exploiting the child for some other end, something no perfect being could do. Indeed, it's worse than imperfect; it's morally monstrous.

If anything, this frequent refrain about the sacrosanct value of human freedom shows just how alien theism is to our ordinary moral outlook. If you decide to play the role of spectator while a child is tortured, even though you could easily stop the torture at no risk to yourself, ordinary morality won’t excuse your inaction because you didn’t want to curtail the torturer's freedom. ${ }^{8}$ It's hard to see why theists imagine that the very same excuse could exonerate a morally perfect God. ${ }^{9}$

\section{Heaven and retrospective consent}

According to a theodicy I call "Heaven Swamps Everything,” compensation paid to an exploited individual can justify or excuse the original exploitation, provided the compensation is big enough. On this view, God can justifiably let a child be tortured provided that God eventually sends the child to heaven, even if the child's suffering is in no way necessary for attaining heaven. Again, however, such reasoning conflicts with ordinary morality because it conflates compensation and justification, and it may stem from imagining an ecstatic or forgiving state of mind on the part of the heaven-dweller: in heaven no one bears grudges, even the most horrific earthly suffering is as nothing compared to heavenly bliss, and all past wrongs are forgiven. But “are forgiven” doesn’t mean “were justified”: the blissful person’s disinclination to dwell on his

\footnotetext{
${ }^{8}$ As Derk Pereboom notes, from the ordinary moral perspective "the evildoer's freedom is a weightless consideration, not merely an outweighed consideration” (Pereboom 2005: 84, citing and expanding on Lewis 1993: 155).

${ }^{9}$ For a more detailed refutation of the free-will reply, see Maitzen 2009: 120-122.
} 
or her earthly suffering doesn’t imply that a perfect being was justified all along in allowing it. By the same token, our ordinary moral practice recognizes a legitimate complaint about child abuse even if, as adults, its victims should happen to be on drugs that make them uninterested in complaining. Even if heaven swamps everything, it doesn’t thereby justify everything.

Alternatively, one might suppose that, assuming everyone goes to heaven, everyone on due reflection eventually consents (after the fact) to any undeserved and otherwise involuntary suffering he or she experienced while on earth. ${ }^{10}$ But this response does nothing to the diminish the theistic threat to ordinary morality: our ordinary moral obligation to prevent at least some undeserved, involuntary human suffering disappears on the assumption that its victims will always on due reflection eventually consent to that suffering. ${ }^{11}$

\section{God's commands}

Theists might reply that we have a moral obligation to prevent suffering, at least on some occasions, not because such suffering is bad overall for the sufferer but simply because God has commanded us to prevent suffering. In that case, allegedly, theism would be consistent with our ordinary moral obligations after all.

This reply fails for three reasons. First, it requires what Jeff Jordan calls a "recalibration" of ordinary morality: "the replacement of concern and sympathy and compassion with the obedience to commands. One alleviates suffering not out of compassion for the sufferer, but

${ }^{10}$ Compare Alston 1996: 112, which defends a view quite close to this one.

${ }^{11}$ Yet another view is that intense suffering is always a gift from God, a blessing, in part because it is an analogue of Christ's suffering. Christopher Hitchens attributes this view to Mother Teresa of Calcutta (Hitchens 1995: 41). Even if we ignore the highly questionable features of this view, it fails to blunt the theistic threat to morality for which I argue here, since if intense suffering is always a blessing in disguise, we never have an ordinary moral obligation to prevent it. 
rather because one is told to do so" (Jordan 2004: 176). Therefore, even if this reply manages to rescue a duty to prevent involuntary, undeserved suffering, it doesn't rescue the ordinary duty to prevent such suffering out of compassion for its victim, because again the suffering in question is necessary or optimal for the sufferer's greater good if God exists.

Second, the reply has the puzzling upshot that God has commanded us to prevent undeserved, involuntary human suffering, at least when we easily can, even though such suffering always benefits the sufferer overall. Why, then, have us prevent it? Notice that distinguishing acts from rules won't help here, at least not if the sufferer's well-being is our paramount concern, as it should be. Rule utilitarians say that they can consistently endorse a rule adherence to which sometimes fails to maximize utility provided that following the rule generally maximizes utility. I’ve argued, however, that our following the rule "Prevent involuntary, undeserved suffering” never maximizes the sufferer's utility if God exists, because we never thereby increase the sufferer's total utility relative to what God would have secured for him or her in any case. Not even the staunchest rule utilitarian will endorse a rule requiring us to prevent suffering if following the rule never increases the sufferer's utility.

Third, just where has God commanded us to prevent suffering? That particular command isn’t easy to find in the monotheistic scriptures, to put it mildly. Moreover, we've seen that a generic command to act compassionately doesn’t translate, if God exists, into a command to prevent suffering. For a command to act compassionately isn't a command to show misguided compassion-for instance, compassion that causes someone to prevent even those vaccinations that greatly benefit their recipients. By the same token, then, God doesn’t command equally misguided compassion compelling us to prevent suffering that, I’ve argued, must always produce a net benefit for the sufferer. 


\section{An imperfect God?}

In this paper, I've assumed the classical theistic conception of God as possessing perfect knowledge, power, and goodness. Some may try, therefore, to evade my argument by positing a God who lacks one or more of those divine perfections. Because I've argued that the existence of a perfect God would undermine morality, the response “Well, that's not my God!” doesn’t of course refute my argument so much as it changes the subject. But let me give what I think are compelling reasons not to change the subject.

Serious theological problems arise for those who imagine that their God has limitations and imperfections. To begin with, this view of God rules out any a priori arguments for God's existence, such as the ontological argument, that proceed from the mere concept of a perfect being; indeed, it abandons the entire project of perfect-being theology. But worse, this view invites all manner of awkward questions about the God it imagines. If God is imperfect, why think that God always has existed and always will exist? An imperfect God might be only finitely old and might go out of existence just when we need him most! If God is imperfect, why think that God has the power to make the universe out of nothing, or even the power to fashion the universe out of pre-existing stuff, or the power to achieve justice in the end? The affirmation "With God, all things are possible"12 is supposed to comfort believers, but if God is imperfect, what assurance do they have that all things are possible with God? Classical theism avoids those awkward questions by insisting on God's perfection. Furthermore, the more limited and imperfect one imagines God to be, the more God resembles the deities that polytheistic religions invoke to explain various aspects of the natural world: a god for the Sun, another for the Moon,

${ }^{12}$ Matthew 19:26 (KJV); for similar affirmations, see also Job 42:2, Jeremiah 32:17, and Luke 1:37, all cited in Leftow 2011: 106. 
another for fertility, and so on. But surely deities of that sort have been outmoded by science's ability to explain those aspects of the universe in purely naturalistic terms.

With respect to perfect knowledge in particular, the non-classical version of theism known as "open theism” claims that God lacks infallible knowledge of the future, or at least the part of the future that depends on the libertarian free choices of creatures. But this departure from classical theism doesn’t evade my argument. For even on open theism, God can surmise (and surely better than we can) that a child is about to be tortured by a libertarian free agent or, at a minimum, that the agent is likely to continue the torture once it's underway. ${ }^{13}$ It doesn't take anything close to infallible knowledge to make those judgments. Possessing the requisite power and benevolence, therefore, even the God of open theism would prevent child-torture (or its continuation) unless again, in God's supernaturally best judgment, it was necessary or optimal for the child's greater good. Hence open theism fails to avoid the dire implications for morality that I’ve argued stem from classical theism.

In my experience, those who respond to my argument by invoking God’s imperfection more often portray God as lacking the power to prevent suffering that he sees coming and would prevent if only he could. ${ }^{14}$ Again, problems arise for any view that retreats on God's power. First, even if God may lack the power to prevent every case of horrific suffering by children, it strains credulity to think that the suffering that God makes it his priority to prevent would have been even worse than the horrific suffering by children that God does allow to occur.

${ }^{13}$ As William Hasker, himself an open theist, emphasizes in Hasker 2010: 308.

14 See, e.g., Gellman 2010, responding to Maitzen 2009 and replied to in Maitzen 2010. Oddly, Gellman explicitly declares that he's describing a perfect God (ibid., 191), but I see no way to characterize as perfect a God who suffers from the apparently severe limitations in power that Gellman sketches in his article. 
Second, why think that a God lacking perfect power would still possess perfect knowledge, perfect goodness, or indeed perfection in any attribute? The classical Anselmian conception of God famously treats the divine perfections as a package deal: reasoning from the concept of a greatest possible being, we're supposed to conclude that God must have every intrinsically great-making quality in its highest possible degree. On this view, the divine perfections stand or fall together. Hence abandoning one of the perfections requires abandoning all of them, which in turn risks portraying God as merely a powerful extraterrestrial: existing only contingently, finitely old, mortal, and so on. Without the classical Anselmian conception of God, we lack a priori grounds for ruling out that scenario, and it's hard to see how we could have a posteriori grounds for ruling it out either. ${ }^{15}$

Third, and relatedly, once you allow for the possibility of an imperfect God it seems arbitrary to abandon omnipotence rather than omniscience or omnibenevolence. Maybe God knows perfectly well how horrifically children sometimes suffer and could prevent it if he wanted to, but he finds their suffering entertaining or beautifully poignant. Or maybe God lets children suffer horribly precisely so that we can have serious moral obligations to intervene on their behalf, ${ }^{16}$ which I submit would be a morally abominable case of God's exploiting those children. Furthermore, once you admit God's imperfection, where do you stop? If human and animal suffering is evidence at all of God's imperfection, it's by no means clear that it isn't evidence of a radically imperfect God: a God too impotent, or ignorant, or morally indifferent to

${ }^{15}$ See Oppy 2011 for discussion of a similar worry.

${ }^{16}$ As proposed by Hasker 1992 and defended in Hasker 2010. Hasker’s explanation assumes that God has no moral obligation to prevent such suffering, and hence God can't be faulted for letting it occur, even though God's letting it occur creates for us a moral obligation to prevent it if we easily enough can, an obligation we can be faulted for failing to honor. I can't see how God could permissibly delegate such an obligation - that is, delegate it without thereby exploiting the sufferers in a morally objectionable way. 
intervene in any of the cases of undeserved, involuntary suffering we observe-and a far cry from the God that theists say they worship.

To sum up, I’ve argued that the existence of our most basic moral obligations logically implies the nonexistence of any perfect being, such as theism’s perfect God. Logically speaking, morality isn't common ground between theists and atheists. Theism logically precludes, for example, your moral obligation to prevent terrible suffering by a child even when you easily enough can prevent it. In terms, therefore, of the question that motivates this volume-What makes us moral? - the answer is, in part, a logical (if often unacknowledged) commitment to atheism.

\section{References}

Alston, W P (1996) The inductive argument from evil and the human cognitive condition. In Howard-Snyder D (ed) The evidential argument from evil. Indiana University Press, Bloomington, pp 97-125

Edgell, P, et al. (2006) Atheists as 'other': Moral boundaries and cultural membership in American society. Am Soc Rev 71: 211-34

Gellman, J (2010) On God, suffering, and theodical individualism. Eur J Phil Relig 2: 187-191

Hasker, W (1992) The necessity of gratuitous evil. Faith \& Philosophy 9: 23-44

Hasker, W (2010) Defining “gratuitous evil”: A response to Alan R. Rhoda. Relig Stud 46: 303309

Hitchens, C (1995) The missionary position: Mother Teresa in theory and practice. Verso, London, UK

Jordan, J (2004) Divine love and human suffering. Int J Phil Relig 56: 169-178

Kurtz, P (2009) Opening statement by Paul Kurtz. In Garcia R K and King N L Is goodness without God good enough? A debate on faith, secularism, and ethics. Rowman \& Littlefield, Lanham, MD, pp 25-39

Leftow, B (2011) Why perfect being theology? Int J Phil Relig 69: 103-118.

Lewis, D (1993) Evil for freedom’s sake? Phil papers 22: 149-172 
Mackie, J L (1977) Ethics: Inventing right and wrong. Penguin Books, Harmondsworth, UK

Maitzen, S (2009) Ordinary morality implies atheism. Eur J Phil Relig 1: 107-126

Maitzen, S (2010) On Gellman’s attempted rescue. Eur J Phil Relig 2: 193-198

Oppenheimer, M (2010) Atheists debate how pushy to be. New York Times, 16 October, p A12

Oppy, G (2011) Perfection, near-perfection, maximality, and the Anselmian God. Int J Phil Relig 69: $119-138$

Paul, G (2005) Cross-national correlations of quantifiable societal health with popular religiosity and secularism in the prosperous democracies: A first look. J Relig Soc 7: 1-17

Paul, G (2009) The chronic dependence of popular religiosity upon dysfunctional psychosociological conditions. Evol Psych 7: 398-441

Pereboom, D (2005) Free will, evil, and divine providence. In Dole A, Chignell A (eds) God and the Ethics of belief. Cambridge U P, New York, pp 77-98

Rachels, J (1999) The elements of moral philosophy, 3rd edn. McGraw-Hill, Boston, USA

Stump, E (1985) The problem of evil. Faith \& Phil 2: 392-423

Stump, E (1990) Providence and the problem of evil. In Flint T P (ed) Christian philosophy. U Notre Dame P, Notre Dame, Indiana, USA, pp 51-91

Swinburne, R (1995) Theodicy, our well-being, and God’s rights. Int J Phil Relig 38: 75-91 